\title{
NATIONAL EPILEPSY MOVEMENT IN BRAZIL
}

\author{
Paula T. Fernandes ${ }^{1,2}$, MSc, PhD; Ana L.A. Noronhat,2, MD, PhD; \\ Josemir W. Sander ${ }^{3,4}, M D, P h D, F R C P ; L i$ M. Li',2, MD, PhD
}

\begin{abstract}
Purpose: To establish a social network of epilepsy lay organization in Brazil to provide advocacy for people with epilepsy and eventually form a powerful National Epilepsy movement. Method: We actively searched for any associations, support groups or organizations related to epilepsy in the country by personal contacts, internet search and by telephone search. Contact was then established with any entity found. Results: The first meeting was held in Campinas in March 2003, and was attended by 270 people, including many people with epilepsy, members of all eleven epilepsy associations found, health professionals and representatives of the Brazilian chapters of IBE and ILAE and the Brazilian Ministry of Health. This first meeting resulted in a National Movement expressed every year through the National Week of Epilepsy and National Meeting of Lay Associations. Discussion: This strategy, developed by ASPE, was simple and effective, and in a very short time a national movement was active. These actions could be reproduced in any country developing a campaign against epilepsy. It is important to consider that this is a process of empowerment, thus people with epilepsy need to take actions into their own hands and to be active participants.
\end{abstract}

KEY WORDS: national movement, epilepsy, patients' associations.

\begin{abstract}
Movimento nacional de epilepsia no Brasil
RESUMO - Objetivo: Estabelecer uma rede social na epilepsia, através de encontros de associações de pacientes para promover um melhor atendimento bio-psico-social aos pacientes e com isso, formar um Movimento Nacional de Epilepsia. Método: Foram pesquisadas as associações de epilepsia e grupos de apoio existentes em nosso país através de contatos pessoais ou telefônicos e pesquisas pela internet. Resultados: O primeiro encontro aconteceu em Campinas em março de 2003 e contou com a participação de 270 pessoas, incluindo pessoas com epilepsia, membros de 11 associações de epilepsia, profissionais da saúde, representantes dos capítulos brasileiros da ILAE e da IBE e o Ministro da Saúde. Este primeiro encontro resultou em um Movimento Nacional, expresso anualmente através da Semana Nacional de Epilepsia e do Encontro Nacional de Associações e Grupos de Pacientes com Epilepsia. Discussão: Esta estratégia, desenvolvida pela ASPE, é simples e efetiva, mostrando que em um curto período de tempo, o movimento nacional ficou ativo. Estas ações podem ser reproduzidas em qualquer lugar, dentro da campanha "Epilepsia fora das sombras". É importante enfatizar que isso é um processo de fortalecimento, de modo que as pessoas com epilepsia precisam tomar suas próprias decisões, tendo o controle da situação para enfim, serem participantes ativos de todo o processo.
\end{abstract}

PALAVRAS-CHAVE: movimento nacional, epilepsia, associações de pacientes.

Lay associations play an important role in fighting against prejudice and lack of knowledge and in p roviding support to people with epilepsy. They are also important in articulating public policies as they voice patients' perspectives and their anxieties and needs, relating not only to medical issues but also to the society in which they live.

It is known that epilepsy is a stigmatizing condition often leading to difficulties in psycho-social adjustment. Beliefs and misunderstandings about the condition have been found to be important for stigma perpetuation, especially in resource-poor countries. There needs to be common eff o rt towards the construction of a national epilepsy policy, to reduce stigma and to improve the quality of life of people with epilepsy. In this context, it is important that all areas of society should be organized to attain this objective.

Before a movement of national proportions can be started it is necessary to engage the representa-

${ }^{1}$ Department of Neurology, Faculty of Medicine, UNICAMP, Campinas, SP, Brazil; ${ }^{2}$ Assistência à Saúde de Pacientes com Epilepsia ASPE, Campinas, SP, Brazil; ' ${ }^{3}$ Epilepsy Institute of the Netherlands, SEIN, Heemstede, Achterweg 5, 2103 SW Heemstede, the Netherlands; ${ }^{4}$ Department of Clinical and Experimental Epilepsy, UCL Institute of Neurology, London UK. 
tive sectors in diff e rent regions of the country. Thus the objective of this project was the creation of a national network to advocate for people with epilepsy and to educate the population about issues related to epilepsy, in order to minimize the negative facets related to epilepsy and to bring a new perspective on epilepsy.

This project is a National Phase of the Demonstration Project on Epilepsy in Brazil, part of WHO/ ILAE/IBE Global Campaing Against Epilepsy, executed by ASPE, Assistência à Saúde de Pacientes com Epilepsia'. One of the aims of the DP was to establish a social network of epilepsy lay organizations in Brazil to provide advocacy for people with epilepsy and eventually form a powerful National Epilepsy movement.

\section{METHOD}

We actively searched for any associations, support $g$ roups or organizations related to epilepsy in the country by personal contacts, internet search and by telephone search. Contact was then established with any entity found.

\section{RESULTS}

Eleven active associations were found and contacted. All were invited to participate in the $1^{\text {st }} \mathrm{Na}$ tional Meeting of Associations and Support Groups of People with Epilepsy². This meeting was held in Campinas in March 2003, and was attended by 270 people, including many people with epilepsy, members of all eleven epilepsy associations found, health professionals and representatives of the Brazilian chapters of IBE and ILAE and the Brazilian Ministry of Health. An overview of epilepsy in Brazil and possible action plans for the implementation of a national policy for epilepsy were presented and discussed by representatives of the associations. The main re solutions of this first meeting were:

1. Creation of Grupo Ação, a national consortium of epilepsy support groups and associations.

2. C reation of the G rupo Ação Newsletter, an elect ronic newspaper to promote the activities of the association.

3. Production of the "Campinas Manifesto", a declaration of actions to be implemented in the are a of epilepsy, as follows:

\section{Campinas manifesto}

The I National Association and Support Group of Patients with Epilepsy Meeting held on March 29 th 2003 in Campinas - SP in the presence of representatives of the Municipal Health Secretary of Campinas, the Ministry of Health, the following Associations:
ABE (Brazilian Chapter of International Bureau of Epilepsy), APE (Epilepsy Association of Paraná), AMAE (Epilepsy Association of Minas Gerais), ASPESE (Epilepsy Association of Sergipe), APEDF (Epilepsy Association of Federal District), APEPE (Epilepsy Association of Pernambuco), ARPE (Epilepsy Association of Rio $P$ reto), APPESC (Association for patients with epilepsy and convulsive syndromes), ASCAE (Epilepsy Association of Santa Catarina,) the Task Force, the LBE (Brazilian Chapter of ILAE), patients with epilepsy and their families and health care professionals agreed to the creation of Grupo Ação (Action Group), which is formed by the above Associations, the Task Force, the LBE and the Project ASPE. Grupo Ação designates September $9^{\text {th }}$ as National Epilepsy Day and declares that:

- Epilepsy is a neurological condition and a public health problem that, if inadequately treated, causes or accentuates physical, psychological, economic and social problems.

- The reare at least three million people with epilepsy in Brazil, and it is estimated that about $50 \%$ do not receive proper treatment.

- Epilepsy occurs at any age, but especially in children and adolescents, and also in the elderly.

- The mortality rate is higher in people with epilepsy than in the general population.

- Adequate treatment can render the majority of patients seizure - free, improving their quality of life.

- There is a significant amount of prejudice and stigma against people with epilepsy; in great part this is due to lack of knowledge and of correct information.

- The direct and indirect costs of epilepsy are high and can be reduced with the effective treatment of epilepsy

We are inviting the Federal, the State, and the Municipal Governments, the private and public organizations, the health providers, and the general public to join us in this strong and decisive course of action to meet the objectives of the Global Campaign Against Epilepsy coordinated by the World Health O rganization, the International League Against Epilepsy, and the International Bureau of Epilepsy "Epilepsy out of the Shadows". Specifically we urge action to:

- Improve knowledge about epilepsy in the Brazilian population and thereby reduce its stigma.

- Fight discrimination against people with epilepsy in all environments, in particular the school and the work place 
- Educate people with epilepsy and their families to improve their understanding of their condition and to empower them to seek appropriate tre atment and to lead fulfilled lives.

- Fight for the free and continuous distribution of antiepileptic drugs for people with epilepsy.

- Inform health professionals on the treatment of people with epilepsy.

- Strengthen primary health care, emphasizing prevention, diagnosis and treatment by making available modern equipment, trained health personnel, access to the full range of antiepileptic drugs, epilepsy surgery and other forms of treatment.

- Promote research, professional training and education in epilepsy.

- Promote close liaison among governmental, nongovermental and international organizations to develop strategic projects and mobilize resources for epilepsy.

- Promote publication of research data and diff usion of knowledge about epilepsy in Brazil.

- Consolidate national legislation aiming to facilitate the implementation of health policies in accord with the initiatives proposed in this manifesto.

This first meeting resulted in a National Movement expressed every year through the National Week of Epilepsy3,4 and National Meeting of Lay Associations $^{2,5,6}$.

\section{DISCUSSION}

The first meeting held in Campinas was a turning point, as prior to this there was no sense of a national epilepsy movement, and the associations across the country were working in isolation. In three years we witnessed a growth in the number of associations involved, and several initiatives were proposed. These initiatives were successful, and represented an important step towards promoting awareness of epilepsy, decreasing the associated prejudice and stigma, and i $\mathrm{m}$ p roving the quality of life of people with epilepsy and their families, throughout the mass awareness campaign.

The national movement empowers the lay associations. It has now become an influential voice with a representative in the National Health Council and on the Forum of Chronic Pathology.

The strategy developed by ASPE was simple and e ffective, and in a very short time a national movement was active. These actions could be reproduced in any country developing a campaign against epilepsy. It is important to consider that this is a process of empowerment, thus people with epilepsy need to take actions into their own hands and to be active participants.

\section{REFERENCES}

1. Li LM, Sander JW. National demonstration project on epilepsy in Brazil. Arq Neuropsiquiatr 2003;61:153-156.

2. Fernandes PT, Noronha AL, Cendes F, Silvado C, Guerreiro CA, Li LM. Relatório do I Encontro Nacional de Associações e Grupos de Pacientes com Epilepsia. J Epilepsy Clin Neurophysiol 2003;9:93-96.

3. Fernandes PT, Souza RJ, Li LM. Relatório da II Semana Nacional de Epilepsia. J Epilepsy Clin Neurophysiol 2004;10:245-247.

4. Fernandes PT, Souza RI, Li LM. Relatório da III Semana Nacional de Epilepsia. J Epilepsy Clin Neurophysiol 2005;11:205-207.

5. Fernandes PT, Leitão LM, Souza RJ, Li LM. Relatório do II Encontro Nacional de Associações e Grupos de Pacientes com Epilepsia. J Epilepsy Clin Neurophysiol 2004;10:117-120.

6. Fernandes PT, Souza RJ, Li LM. Relatório do III Encontro Nacional de Associações e Grupos de Pacientes com Epilepsia. J Epilepsy Clin Neurophysiol 2005;11:97-99. 